\section{Determinants of Delays in Corporate Reorganizations}

\author{
Vinicius Augusto Brunassi Silva ${ }^{1}$ \\ ${ }^{1}$ FECAP, Finance, Sao Paulo - SP, Brazil \\ Richard Saito ${ }^{2}$ \\ ${ }^{2}$ FGVIEAESP, Finance, Sao Paulo - SP, Brazil \\ Paulo Martins Manoel ${ }^{3}$ \\ ${ }^{3}$ University of Kentucky, Finance, Kentucky, USA
}

\author{
Mariana Aparecida Calabrez Oreng ${ }^{4}$ \\ ${ }^{4}$ FGVIEAESP, Finance, Sao Paulo - SP, Brazil
}

Received on:

06/30/2018

Approved on:

07/31/2019

Responsible Editor:

Prof. Dr. Javier Montoya Del Corte

Evaluation process:

Double Blind Review

\begin{abstract}
Purpose - Firms and creditors may delay certain decisions in corporate reorganizations because of actions that require coordination. This paper investigates delays in voting on reorganization plans during claimholder general meetings in Brazil.
\end{abstract}

Design/methodology/approach - Using a sample of 120 hand-collected reorganization plans, we present descriptive and regression (OLS, Poisson, negative binomial, and quantile) analyses to show the primary characteristics of delayed votes.

Findings - Our results revealed that a high concentration of debt among the different classes of claimholders appeared to be related to fewer delays. Moreover, a higher number of banks and secured creditors with claims in the reorganization appeared to be positively correlated with delays. Finally, we argue that reorganization plans that require additional time to reach a vote are related to divestment proposals.

Originality/value - There is still a lack of empirical results based on evaluations of multiple creditor characteristics and the reorganization proposals presented in firms' reorganization plans. This is the first paper in Brazil to explore how conflicts of interest among different classes of creditors may relate to delays. Our paper contributes to the literature developed by Gilson (1990), Gilson et al. (1990), Brown et al. (1993), Franks and Tourus (1994), Helwege (1999), Ayotte and Morrison (2009), Ponticelli (2012), and Ivashina et al. (2015) regarding the characteristics of delaying reorganization plan votes during restructuring cases. We corroborate the results obtained by previous papers and provide an analysis of the role played by each class of claimholder in delaying plan votes for Brazilian firms

Keywords - Delay; corporate reorganization; creditors' meeting; bankruptcy law

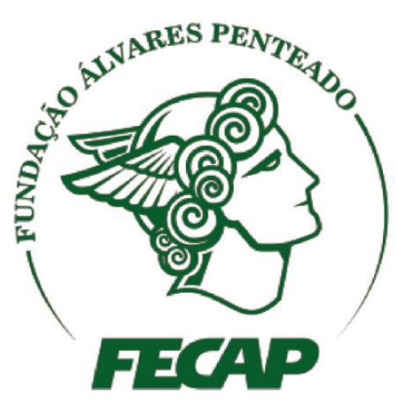

Revista Brasileira de Gestáo de Negócios 


\section{Introduction}

This paper uses a novel database of delays in the reorganization of bankrupt companies. Previous literature notes the importance of coordination and bargaining during the reorganization period, in which information asymmetry and conflicts of interest appear to play a crucial role. Theoretical evidence on bargaining theory states that a considerable delay in reaching an agreement may occur when there are informational disparities between parties (Kennan \& Wilson, 1990) and when the number of bargainers is large (Cai, 2000).

Focusing on Chapter 11 and Chapter 7 bankruptcies, the aforementioned researchers noted that delays can occur in imperfect information models when parties share bargaining power. Chapter 11 reduces coordination problems by grouping creditors into classes according to their claims in court reorganizations. In practice, however, contracts appear to be incomplete and investors and the court system are unable to provide sufficient conditions for enforcing all rights. The holdout problem increases the difficulty of resolving financial distress and creditors or debtors may occasionally prefer to postpone voting on a reorganization plan to demand more agreeable and reliable conditions.

According to Ivashina, Iverson, and Smith (2016), claim administrators are hired by Chapter 11 debtors to organize and provide information on all claims and claimholders. The administrators are representative agents who obtain creditors' decisions about the restructuring plan. Nevertheless, the bargaining conditions related to a delay in voting on the reorganization plan cannot be evaluated for each creditor that is available to vote in all classes because creditors do not meet in an assembly.

Because of the absence of appropriate US data on the subject, knowledge on delays in the reorganization plans of distressed firms is limited. For example, creditor committees in the US generally include representatives of only unsecured creditors. Hence, it is difficult to identify how the different classes of creditors decide to vote on or postpone the reorganization plan in each case. The interests of distinct groups may frequently diverge in reorganization cases. Therefore, the data provided by the committees' representation might not adequately capture the reasons related to each delay period. This paper's objective is to identify these reasons.
In Brazil, unlike the US, creditors meet to vote on reorganization plans. The minutes of the assembly record the events of such meetings, providing evidence of creditor demands for additional changes and debtor responses to claimholders' considerations and suggestions. Moreover, it is possible to observe which creditors showed up to vote on the plan, their claims, and the outcome of the vote. We argue that such conditions enable us to obtain valuable information about the characteristics of decisions related to delaying votes because of the ability to observe the process undertaken when different classes and types of creditors meet in creditors' meetings and decide to postpone a reorganization vote.

We explore descriptive statistics of reorganizations and controlled correlations in our regressions without suggesting causality. To the best of our knowledge, there is still a lack of empirical results based on evaluations of multiple creditor characteristics and the reorganization proposals presented in firms' reorganization plans. This is the first paper in Brazil to explore how conflicts of interest among different classes of creditors may relate to delays (more days to vote on the reorganization plan) in reorganization processes after the new Brazilian bankruptcy law.

This paper follows a strategy similar to that of Kaplan and Stromberg (2002) by highlighting the descriptive statistics of databases that suffer from sample bias, which cannot be excluded by quasi-experiments. For that reason, we do not address causality in our study. Because we cannot control for previous capital structure decisions, liquidity levels, and other financial statement variables that make the resolution of distress more (or even less) complex during the reorganization process, our regressions may present some bias attributable to the omitted variable problem.

The decision to delay a reorganization plan vote may damage creditors and firms in Brazil in several ways. Creditors cannot receive any value before the reorganization plan vote. The money to be recovered by the creditors will not earn interest during the delay. This is particularly important in Brazil, which has one of the highest interest rates in the world. In addition, banks must make a provision for $100 \%$ of the amount borrowed in reorganization cases as a guarantee of operation. This may reduce bank interest because banks earn less in these situations compared with other market alternatives. Firms 
cannot obtain new resources to continue their operations until creditors decide on reorganization or liquidation. Longer delays to vote on a reorganization plan can increase the difficulty of the reorganization.

Unlike creditor committees in the US, official creditor committees are rarely formed in Brazil. In general, creditor committees in Brazil have three types of representatives: labor, the secured class, and the unsecured class. We did not include the fourth class of creditors because the number of cases in our database was minimal.

Our data originated from firms and the websites of certain judicial trustees in Brazil and they are composed of 120 reorganization plans dating from 2005 to 2015. We chose to begin in 2005 because the new Brazilian bankruptcy law was enacted that year. Therefore, our study provides information about the resolution of the financial distress of firms in Brazil considering 10 years of data following the enactment of the new Brazilian bankruptcy law.

In our sample, we observed certain cases in which creditors required more than 100 days to vote on the reorganization plan. The highest quartile of our sample revealed that an average of 101 days was required to vote on the reorganization plan. After studying the characteristics of the different types of delays, we were able to show that the average delay is longer when all the different classes are in charge of voting on the reorganization plan, whereas the delay decreases considerably when only one class is voting on the plan. By segregating the economic distress analyses, we found that the average delay is longer for lower levels of economic distress (sector return) for both secured and unsecured creditors.

Our results revealed that a high concentration of debt among the different classes of claimholders appeared to be related to fewer delays. Moreover, a higher number of banks and secured creditors with claims in the reorganization appeared to be positively correlated with delays. We did not find statistically significant results regarding the number of labor and unsecured creditors in our regressions.

Finally, we argue that reorganization plans that require additional time to reach a vote are related to divestment proposals. The minutes of the general meetings show that many rounds of discussion are required to determine the assets that should be sold to generate cash. The creditors usually noted the minimum acceptable price to be adopted. In addition, firms encounter certain difficulties in obtaining the permission of secured creditors to sell assets that were allotted to the creditors as collateral before the reorganization period.

Our paper contributes to the literature developed by Gilson (1990), Gilson, John, and Lang (1990), Brown, James, and Mooradian (1993), Franks and Tourus (1994), Helwege (1999), Ayotte and Morrison (2009), Ponticelli (2012), and Ivashina et al. (2016) regarding the characteristics of delaying reorganization plan votes during restructuring cases. We corroborate the results obtained by previous papers and provide an analysis of the role played by each class of claimholders in delaying reorganization plan votes for Brazilian companies.

The structure of this paper proceeds as follows. The second section discusses the related literature and provides information about the types of delays for reorganization plan votes under Brazilian bankruptcy law. The third section presents a description of our data, and the fourth section describes our empirical analysis strategy. The fifth section provides our empirical results, and the sixth section presents our conclusions.

\section{Delays during the firm reorganization process}

We were able to identify the outcomes of Chapter 11 filings and post-bankruptcy performance by reviewing papers by Gilson (1990), Hotchkiss (1995), and Kalay, Singhal, and Tashjian (2007). Despite the significant contributions that have been made on the topic of reorganization, there has not yet been a comprehensive and in-depth analysis of the delays that occur during the reorganization process.

The dynamic bargaining theory is rich and supports predictions of the time needed for resolutions. The classic model of Rubinstein (1982) predicts immediate agreement for subgame perfection under symmetrical information. Admati and Perry (1987) study a bargaining game with incomplete information to understand the time between offers, finding that a time delay signals a bargainer's strength. Studies on delays are also carried out in other areas of knowledge (Das, Ghosh, and Subudhi, 2014; Zhang, Knopse, and Tsiotras, 2001).

Gale (1995) argues that delays are inefficient because social gain does not occur when players discount the future. In coordination games, it can be beneficial for 
an individual investor to delay; however, investors would be better off overall if they make an immediate decision. Theoretical evidence also supports the occurrence of delays when there are informational disparities between the parties (Kennan \& Wilson, 1990) and the number of bargainers is large (Cai, 2000).

Adler, Capkun, and Weiss (2012) find that delays may occur when managers can interfere in the decision about whether a company should file a bankruptcy petition. According to Section 1102 of Chapter 11, a committee of creditors represents the interests of the claimholders during the reorganization process; therefore, it is difficult to evaluate the interactions between creditors from different classes when voting on a reorganization plan. Ivashina et al. (2016) show that creditor concentration is a key variable that explains the speed of recovery during restructurings, and they provide evidence that ownership concentration (total claims owned by the ten largest creditors) is strongly associated with bankruptcy outcomes.

In addition, numerous papers have suggested that the level of bank debt has an impact on bankruptcy claims; such papers include those of Asquith, Gertner, and Scharfstein (1994), Brown et al. (1993), Gilson (1990), Gilson et al. (1990), and James (1996). For instance, Helwege (1999) finds that bank debt is positively related to lower levels of debt restructuring.

According to Baird and Ramussen (2002), Broadie, Chernov, and Sundaresan (2007), Kalay, Singhal, and Tashjian (2007), and LoPucki (2003), senior creditors dominate court-supervised reorganizations. They show that firms with more classes of debt present less improvement in their performance.

Other papers highlight the importance of the new Brazilian bankruptcy law. Senbet and Wang (2010) point out that the old version of the law was inefficient. Anapolsky and Woods (2013) provide a comparison between Brazilian bankruptcy law and the Chapter 11 and Chapter 7 codes. They show improvements in the Brazilian law. Araujo, Ferreira, and Funchal (2012) present that firms faced higher levels of long-term debt and a reduction in their cost of capital when Law 11,101 took effect in Brazil. Silva and Saito (2018) study the approval of reorganization plans and Silva, Sampaio, and Gallucci (2018) analyze the relationship between reorganization requests and macroeconomic variables.
This paper presents evidence of delays in enacting recovery plans based on the concentration of debt, the number of creditors, and the role of banks. The next section includes a brief explanation of the reorganization plan voting process in Brazil.

\section{I How is delaying a plan vote possible under Brazilian bankruptcy law?}

After 2005, the Brazilian financial restructuring procedure came to closely resemble the procedure used in Chapter 7 and Chapter 11 bankruptcies under American law. The Brazilian bankruptcy law also provides distressed companies with the possibility of choosing either in-court or out-of-court recovery. The three classes of creditors (labor, secured, and unsecured) can choose to either approve or reject the reorganization plan. When a claimholder does not agree with the plan's conditions, the creditors must meet in an assembly to vote on the plan.

Creditors are divided into three classes for votecounting purposes. Labor creditors are classified as Category I, secured/guaranteed creditors are classified as Category II, and unsecured creditors are classified as Category III. In general, tax creditors and creditors holding loans supported by the fiduciary alienation of assets are not subject to recovery; therefore, they do not participate in the voting session for the approval of the plan.

Votes must obtain the consent of the three classes of creditors. For secured and unsecured creditors, the plan must be accepted by a majority of creditors at the meeting, and at least half of the total debt value for each class must be represented. Labor debt approval requires a majority of the creditors' votes. If the plan is not approved, the firm faces bankruptcy.

The first opportunity to delay a reorganization plan vote occurs in the first assembly. At first call, there is a minimum quorum requirement to begin the meeting (over half of the claimants from each class of debt). Thereafter, there is no quorum requirement.

It is important to highlight one of the differences between Brazilian bankruptcy law and Chapter 11 . In Brazil, claimholders cannot vote by mail, and creditors must attend the general meeting if they want to vote on the reorganization plan. However, a legal representative is allowed to represent a creditor after authorization from the judicial trustee. 
Another valuable point to consider is the separate treatment of claims in the Brazilian bankruptcy law. Compared with US law, Brazilian law considers each single creditor when counting votes. The differences in Brazilian law may be related to quorum delays because attending the meeting or hiring a representative agent can be costlier than the amount of money that a given creditor has available. Therefore, delays become a matter for bargaining because there is no quorum requirement after the first general meeting.

\section{Data description}

We collected claim-level data from 120 Brazilian firms that filed for reorganization after 2005 (the year the new Brazilian bankruptcy law was enacted). A small portion of our data originated from one of the main Brazilian courts (Vara de Falências e Recuperação Judicial) in São Paulo, with the remaining data obtained from firms and the website of some judicial trustees. We have 24, 20, 19, and 10 cases in 2012, both 2009 and 2013, 2011 , and 2010, respectively. The remaining years present fewer than 10 cases each in our sample.

Because few public companies in Brazil have filed for reorganization since 2005, the majority of our sample originated from private firms. Both public companies and private firms can be classified as corporations (S.A.) under Brazilian law. Private companies are classified as corporations if the company is permitted to issue corporate bonds (S.A) and as noncorporations ( $L T D A)$ if the company is not permitted to issue corporate bonds.

We obtained our data from three documents used in the reorganization process: the reorganization plan, the minutes from the general meetings, and descriptions of the amount of money to be recovered by each creditor.

The reorganization plan must present a general description of the company, a detailed description of the claimholders' payments, the method of reorganization to be adopted, and a professional evaluation of the assets that belong to the firm in recovery.

The minutes from the general meeting provide information on the quorum process, the money represented by each class of creditors voting on the plan, the discussions and suggestions that occur during the meeting, and the decisions made by each class of creditors regarding their acceptance or rejection of the plan through their votes.
When an individual (a firm's lawyer or an individual claimholder) proposes to avoid voting on the plan during the meeting, the judicial trustee registers the result of the voting delay and sets the date and location for the next vote by the creditors on the reorganization plan and the modifications.

The creditors must detail the funds that they are owed, providing information on the amount of money owed to each creditor in the labor, secured, and unsecured classes. Therefore, we can access not only the total amount of money that a company must pay to each class but also the amount of money associated with each creditor's claim. Table 1 summarizes the basic statistics for each variable collected from the documents mentioned above.

We found that the average age of the studied firms (from birth to restructuring date) was approximately 31 years. Approximately seven banks are predominant during restructuring. The descriptive statistics show that the firms received funding from 18 different banks. We present our summary statistics in Table 2 by grouping the information according to the characteristics of the delay. The sample was divided into groups based on the time of delay. We separate all observations according to no delay, delays up to 10 days, delays between 10 days and one month, delays between one and two months, and delays longer than two months. The table provides information about the number of meetings that occurred according to the average delay, the number of banks participating in the reorganization, the age of the recovering company, the quantity and debt share of claimholders from each class able to vote on the plan, and the share of total claims owed to the ten largest creditors (with and without banks).

The sample has a higher concentration of shorter delays (delays up to a maximum of 10 days), which usually occurred because of quorum requirements during the first general meeting. For periods of up to a maximum of 10 days, a maximum of two meetings occurred. Delays of one or two months were less dispersed, whereas delays longer than two months were more dispersed.

Table 3 reports the characteristics of the same variables according to sector and region. We grouped all the companies according to the sector classification presented by Bloomberg. We obtained observations for the following six sectors: basic materials, cyclical, noncyclical, energy, industrial, and utilities. 
Table 1.

Summary statistics

\begin{tabular}{|c|c|c|c|c|c|}
\hline Statistic & $\mathbf{N}$ & Mean & St. Dev. & Min & Max \\
\hline Number of meetings & 120 & 1.90 & 0.85 & 0 & 4 \\
\hline Labor\# & 104 & 117.62 & 244.96 & 0 & 1,406 \\
\hline Secured\# & 116 & 2.89 & 4.38 & 0 & 31 \\
\hline Unsecured\# & 110 & 220.01 & 279.04 & 0 & 1,414 \\
\hline Delay & 116 & 24.71 & 49.80 & 0 & 394 \\
\hline Top 10(\%) & 109 & 0.68 & 0.18 & 0.17 & 0.99 \\
\hline Top 10 (\% - no banks) & 109 & 0.34 & 0.23 & 0.003 & 1.00 \\
\hline Labor_Debt & 119 & $2,771,084.00$ & $11,377,512.00$ & 0.00 & $108,545,963.00$ \\
\hline Secured_Debt & 119 & $18,420,805.00$ & $47,403,693.00$ & 0.00 & $286,942,841.00$ \\
\hline Unsecured_Debt & 119 & $139,681,989.00$ & $542,888,708.00$ & 0.00 & $5,047,800,816.00$ \\
\hline Banks\# & 109 & 6.77 & 3.76 & 0 & 18 \\
\hline Debt (no banks) & 114 & $81,999,519.00$ & $322,983,212.00$ & 0.00 & $3,278,966,037.00$ \\
\hline Bank_loan & 119 & $67,489,485.00$ & $272,337,024.00$ & 0.00 & $2,262,094,199.00$ \\
\hline Age & 111 & 31.32 & 23.23 & 4 & 120 \\
\hline Class concentration & 119 & 0.83 & 0.16 & 0.42 & 1.00 \\
\hline Sector return & 120 & 0.712 & 0.01 & 0.032 & 0.096 \\
\hline Payment years & 114 & 10.56 & 4.14 & 3 & 22 \\
\hline
\end{tabular}

Note: This table reports the summary statistics of the sample of reorganizations. Number of meetings reveals the number of meetings conducted to vote on the reorganization plan. Labor \#, Secured \#, and Unsecured \# are the number (quantity) of labor, secured, and unsecured debtholders. Delay is the time interval (in days) between the first meeting and the plan vote. Banks \# is the number of banks (quantity) to vote on the plan. Labor Debt, Secured Debt, and Unsecured Debt are the amount of labor, secured, and unsecured debt, respectively. Top 10 (\%) is the proportion of the debt held by the 10 debtholders with the highest amount of debt, and Top 10 (\%, no banks) is the proportion of the debt held by the 10 debtholders with the highest amount of debt, excluding banks. Age represents the years of each firm from birth to reorganization. Class concentration is the maximum debt (as a proportion of the total debt) held by a single class of debtholders. Sector return is the average EBITDA for the past 3 years divided by the total book value of all listed companies of a given sector. Payment years reveals the time (in years) for a firm to settle its debt.

Table 2.

\section{Summary statistics per range of delays}

\begin{tabular}{|c|c|c|c|c|c|}
\hline \multicolumn{6}{|c|}{ Characteristics by delay group } \\
\hline Delay Interval: & No Delay & $\geq 1 \mathrm{~d},<10 \mathrm{~d}$ & $\geq 10 \mathrm{~d},<1 \mathrm{M}$ & $\geq 1 \mathrm{M},<2 \mathrm{M}$ & $\geq 2 \mathrm{M}$ \\
\hline Avg. Delay & 0 & 8 & 19 & 47 & 81 \\
\hline NOBS & 45 & 33 & 14 & 14 & 14 \\
\hline$\%$ & $37.5 \%$ & $27.5 \%$ & $12 \%$ & $12 \%$ & $12 \%$ \\
\hline \# Meetings & 1.1 & 2.0 & 2.3 & 2.6 & 3.2 \\
\hline \# Banks & 5.6 & 5.2 & 8.0 & 7.0 & 5.5 \\
\hline Age & 36 & 26 & 22 & 45 & 23 \\
\hline Labor Debt (\%) & $2 \%$ & $4 \%$ & $2 \%$ & $7 \%$ & $2 \%$ \\
\hline Sec Debt (\%) & $19 \%$ & $13 \%$ & $20 \%$ & $15 \%$ & $25 \%$ \\
\hline Unsec Debt (\%) & $77 \%$ & $83 \%$ & $78 \%$ & $78 \%$ & $74 \%$ \\
\hline Labor \# & 459 & 381 & 47 & 488 & 31 \\
\hline Sec \# & 3 & 2 & 3 & 3 & 3 \\
\hline Unsec \# & 430 & 205 & 304 & 277 & 198 \\
\hline Top $10(\%)$ & $67 \%$ & $68 \%$ & $71 \%$ & $67 \%$ & $74 \%$ \\
\hline Top 10 (\%, no banks) & $36 \%$ & $40 \%$ & $20 \%$ & $32 \%$ & $27 \%$ \\
\hline
\end{tabular}

Note: NOBS is the number of observations, \% is the number of observation in each group divided by the total number of observations, Avg. Delay is the average delay (in days) in each group, \# Meetings is the average number of meetings in each group, \# Banks is the average number of banks in each group, Age is the average age in each group, Labor Debt (\%) is the proportion of labor debt (in terms of the total debt of the company). Top 10 (\%) is the proportion of the debt held by the 10 debtholders with the highest amount of debt, and Top 10 (\%, no banks) is the proportion of the debt held by the 10 debtholders with the highest amount of debt, excluding banks. We divided the sample based on the delay $(\mathrm{d}=$ days and $\mathrm{M}=$ months $)$. 
Table 3.

Summary statistics based on sector and region

\begin{tabular}{|c|c|c|c|c|c|c|}
\hline \multicolumn{7}{|c|}{ Characteristics by sector } \\
\hline Bloomberg Sector: & Basic Materials & Cyclical & Non-cyclical & Energy & Industrial & Utilities \\
\hline Delay & 35 & 22 & 18 & 50 & 19 & 11 \\
\hline NOBS & 2 & 18 & 38 & 4 & 44 & 14 \\
\hline$\%$ & $2 \%$ & $15 \%$ & $32 \%$ & $3 \%$ & $37 \%$ & $12 \%$ \\
\hline \# Meetings & 2.5 & 2.1 & 1.7 & 2.5 & 1.9 & 2.0 \\
\hline \# Banks & 5.5 & 4.5 & 6.4 & 9.5 & 5.9 & 5.7 \\
\hline Age & 10 & 49 & 32 & 28 & 28 & 22 \\
\hline Labor Debt (\%) & $2 \%$ & $2 \%$ & $2 \%$ & $2 \%$ & $5 \%$ & $4 \%$ \\
\hline Sec Debt (\%) & $19 \%$ & $10 \%$ & $23 \%$ & $5 \%$ & $13 \%$ & $27 \%$ \\
\hline Unsec Debt (\%) & $79 \%$ & $87 \%$ & $72 \%$ & $93 \%$ & $82 \%$ & $69 \%$ \\
\hline Top $10(\%)$ & $78 \%$ & $74 \%$ & $67 \%$ & $73 \%$ & $68 \%$ & $65 \%$ \\
\hline Top 10 (\%, no banks) & $62 \%$ & $37 \%$ & $36 \%$ & $25 \%$ & $32 \%$ & $27 \%$ \\
\hline \multicolumn{7}{|c|}{ Characteristics by geographic region } \\
\hline Region: & Center West & North & Northeast & South & Southeast & \\
\hline Delay & 23 & 55 & 0 & 19 & 19 & \\
\hline NOBS & 21 & 2 & 2 & 36 & 59 & \\
\hline$\%$ & $17.5 \%$ & $2 \%$ & $2 \%$ & $30 \%$ & $50 \%$ & \\
\hline \# Meetings & 2.3 & 3.0 & 0.5 & 1.9 & 1.8 & \\
\hline \# Banks & 5.5 & 18.0 & 2.0 & 5.3 & 6.4 & \\
\hline Age & 21 & 50 & 42 & 39 & 30 & \\
\hline Labor Debt (\%) & $2 \%$ & $5 \%$ & $5 \%$ & $6 \%$ & $2 \%$ & \\
\hline Sec Debt $(\%)$ & $23 \%$ & $9 \%$ & $27 \%$ & $12 \%$ & $19 \%$ & \\
\hline Unsec Debt (\%) & $75 \%$ & $87 \%$ & $68 \%$ & $80 \%$ & $79 \%$ & \\
\hline Top $10(\%)$ & $70 \%$ & $55 \%$ & $70 \%$ & $63 \%$ & $71 \%$ & \\
\hline Top 10 (\%, no banks) & $34 \%$ & $12 \%$ & $55 \%$ & $31 \%$ & $35 \%$ & \\
\hline
\end{tabular}

Note: Variables are defined in Table 2. We divided the sample based on the Bloomberg sector (first part) and the region (second part).

Our sample is primarily concentrated in the industrial and non-cyclical sectors and less concentrated in the basic materials sector. The average delay is longer for firms from the energy sector, whereas it is shorter for firms in the utilities sector. It is also interesting to observe that the number of banks is higher for firms in the energy sector. The highest concentration of firms in our sample is in the Southeast and South. However, the highest average delay occurred in the North (where there were two reorganization cases).

The delay characteristics of the sample are divided by the cause of the delay and the group causing the delay and they are presented in Table 4 . In this table, we separated the delays that originated from the quorum from delays that occurred because modifications to the original plan were demanded by creditors or because additional time was required by the company to perform the modifications.

By segregating the sample into debt classes according to groups of claimholders, we observe that a higher number of labor creditors are involved in cases that have delays caused by this class. However, we discover that these delays are usually caused by a quorum requirement.

\section{I Sample selection issues}

The majority of the data collected for our sample was provided by the firms and the websites of the judicial trustees. Therefore, it is clear that our restructuring firms were not selected at random, and it may appear that our sample is biased towards a particular region. As shown in Table 3, we present a higher concentration of data for the Southeast and South and only a few cases from the North 
Table 4.

Cause of delays in our sample

\begin{tabular}{|c|c|c|c|c|c|}
\hline \multicolumn{6}{|c|}{ Characteristics by cause of delay and by group causing the delay } \\
\hline & \multicolumn{2}{|c|}{ Cause of delay } & \multicolumn{3}{|c|}{ Group causing the delay } \\
\hline & Quorum & Demand & Labor & Sec. & Unsec. \\
\hline Delay & 27 & 11 & 30 & 23 & 14 \\
\hline NOBS & 62 & 58 & 42 & 7 & 11 \\
\hline$\%$ & $52 \%$ & $48 \%$ & $35 \%$ & $6 \%$ & $9 \%$ \\
\hline \# Meetings & 2.4 & 1.4 & 2.4 & 2.3 & 2.1 \\
\hline \# Banks & 6.0 & 5.8 & 5.9 & 7.0 & 5.5 \\
\hline Age & 27 & 36 & 30 & 34 & 25 \\
\hline Labor Debt (\%) & $4 \%$ & $2 \%$ & $6 \%$ & $2 \%$ & $4 \%$ \\
\hline Sec Debt $(\%)$ & $15 \%$ & $20 \%$ & $16 \%$ & $31 \%$ & $18 \%$ \\
\hline Unsec Debt (\%) & $80 \%$ & $77 \%$ & $78 \%$ & $67 \%$ & $77 \%$ \\
\hline Labor \# & 254 & 439 & 385 & 55 & 52 \\
\hline Sec \# & 2 & 3 & 3 & 4 & 3 \\
\hline Unsec \# & 195 & 430 & 244 & 113 & 110 \\
\hline Top $10(\%)$ & $69 \%$ & $68 \%$ & $66 \%$ & $65 \%$ & $72 \%$ \\
\hline Top 10 (\%, no banks) & $34 \%$ & $33 \%$ & $34 \%$ & $22 \%$ & $44 \%$ \\
\hline
\end{tabular}

Note: Variables are defined in Table 2. We divided the sample based on the cause of the delay.

and Northeast. According to Ponticelli (2012), Brazil is divided into 2,738 judicial districts, which can either be treated as a single municipality or encompass a group of municipalities. Twelve judicial districts have specialized bankruptcy courts. Ponticelli indicated that each judicial district in Brazil has 1.6 civil courts on average.

Ponticelli (2012) noted that the state of São Paulo has a congestion of civil courts, which is consistent with our sample because a greater number of observations was obtained from the Southeast, which had more than 10 different courts in São Paulo alone. Ponticelli also showed that court congestion in the Southeast is worse than in other regions and indicated that companies in Brazil are extremely concentrated in the South and Southeast.

Another considerable source of selection bias relates to how the data were electronically collected. Larger companies may have access to additional resources that allow them to put their data online, or they may be able to hire high-powered law firms that can perform this task on their behalf. Because the minutes of the assembly provide information about the lawyer representing the recovering firm and the judicial trustee, we were able to investigate the pattern related to lawyers in our sample data. We found that the cases in our sample are spread among various lawyers. We believe that this dispersion reduces the possibility of grouping faster or slower reorganizations according to a single lawyer, although it does not eliminate the possibility of a particular lawyer specializing in either more complex or easier recovery cases.

Iverson (2017) indicated that firms that reorganize in busy courts spend longer amounts of time in bankruptcy, and when the schedules of the presiding judges are busier, a greater number of reorganization plans are approved.

We were able to analyze the concentration of cases in our sample in the hands of judicial trustees. Table 5 shows the lowest, median, and highest levels of delay for the cases in our sample with seven of the most frequently presiding judicial trustees.

There is a considerable distribution of delays, and one specific trustee is associated with a median delay that is twice as long as that of the other trustees. Therefore, we believe that if bias occurs in our sample, then it is associated with the concentration of cases in certain regions and with specific judicial trustees.

\section{Empirical Analysis Strategy}

Our objective is to present descriptive and econometric analyses based on our results to show the primary characteristics of delayed votes. Our descriptive analysis focuses on the characteristics of voting delays. Here, we are interested in understanding the relationship between the different classes of creditors and delays. First, we separate 
Table 5.

Characteristics of judicial trustees

\begin{tabular}{ccccccc}
\hline Trustee & \# of Firms & Avg. \# of Meetings & Median Delay & $\mathbf{1 0 \%}$ Lower Delay & 90\% Higher Delay & Region \\
\hline$\# 1$ & 20 & 2.00 & 8 & 0 & 52 & Southeast $(95 \%)$ \\
$\# 2$ & 11 & 1.64 & 0 & 0 & 47 & South $(100 \%)$ \\
$\# 3$ & 11 & 1.82 & 7 & 0 & 77 & Southeast $(100 \%)$ \\
$\# 4$ & 8 & 2.00 & 20 & 0 & 63 & South (100\%) \\
$\# 5$ & 6 & 2.67 & 40 & 0 & 98 & Southeast (100\%) \\
$\# 6$ & 5 & 2.60 & 23 & 7 & 67 & Center West (100\%) \\
$\# 7$ & 5 & 2.40 & 8 & 7 & 41 & Center West (100\%) \\
\hline
\end{tabular}

Note: This table reports the characteristics of the reorganizations divided by judicial trustee

the possible types of delay according to their characteristics. Delays are separated into cause (delays caused by quorum requirements) and meeting (delay characteristics in each general meeting). This analysis considers the presence of creditor classes able to vote on the plan.

The last step of this descriptive analysis considers a proxy for economic distress experienced by the firms in the sample. The economic distress proxy is important because the conditions that allow a firm to generate the funds to pay their creditors may relate to more or less complex reorganization cases. We collected the earnings before tax for public companies in Brazil belonging to the same sector concentration of the firms in our data. This analysis focuses on evaluating voting delays when the recovering company belongs to a sector encountering better or worse conditions. The analysis is an additional effort to observe what occurs in cases that can be considered more or less complex.

\section{I Econometric specification}

Although we do not address causality in this paper, we believe that it is important to observe how delays in voting on a plan relate to different variables under certain controlling factors. We perform multiple regressions to analyze the relationship between the delay and the independent variables. The dependent variable is the delay in recovery plan voting calculated in days. Our empirical equation is specified as follows:

$$
\begin{aligned}
& \text { Delay }_{i}=\beta_{0}+\beta_{1} \text { Class_Conc }(\%)_{i}+\beta_{2} \text { Conc_top10 }(\%)_{i}+ \\
& \beta_{3} \text { Number_of_banks } s_{i}+\beta_{4} \text { Number_of } \_L C_{i}+ \\
& +\beta_{5} \text { Number_of_SC } C_{i}+\beta_{6} \text { Number_of_UC } C_{i}+\beta_{7} \text { Type }_{i}+ \\
& \beta_{8} \text { Payment }- \text { years }{ }_{i}+\beta_{9} \operatorname{Sector}-\text { return }_{i}+u_{i}
\end{aligned}
$$

The "Conc" variables indicate the concentration of claims in each of the classes and the share of claims in the top 10 creditors. Because a higher concentration of funding in one claimholder class increases the alignment of all perspectives, creditors are expected to adopt a consensus decision more quickly relative to situations in which the claims are more dispersed between the different classes of creditors (Ivashina et al., 2016).

The "Number_of_Banks" variable presents the number of banks operating in the list of creditors. The variables indicating the number of $\mathrm{LC}, \mathrm{SC}$, and UC show the number of creditors from each group participating in the vote in the assembly (labor, secured, and unsecured creditors). "Type" is a control variable that equals one if the reorganizing firm is S.A and zero if the firm is LTDA. As we cannot control for firm size by looking at the firms' assets (we do not have asset information for private firms), we control for company type to attenuate any possible relationship between firm size and the delay. Moreover, we believe that controlling for firm type and the number of workers (labor class) provides us with a good measure of firm size. The control variable "Payment - years" specifies the period stated by the firm to settle its debt. We expect more bargaining (greater delays) when a firm takes longer to pay the debtholders' debt.

Finally, the "Sector return" variable captures the average EBITDA for the past three years divided by the total book value of all listed companies as a measure of the profitability of a given sector. The level of economic distress may influence the way creditors decide on the future of a company. When the sector faces difficulties, resolving the distress situation can be more difficult.

All further tests maintain the variables adopted in equation 1 . The null hypothesis of our equations is that none of the explanatory variables noted above influences the delay in voting on the plan. The following hypotheses are consistent with those of previous works. 
Hypothesis H1: A concentration of claims (in both classes and top 10) may influence the delay by allowing fewer disparities among creditors (Ivashina et al., 2016). Therefore, we expect a negative sign in our regressions $\left(\beta_{1}\right.$ and $\beta_{2}$ are both $\left.<0\right)$.

Hypothesis H2: The number of banks may influence the delay by increasing both the bargaining process and coordination problems (Helwege, 1999). Therefore, we expect a positive sign in our regressions $\left(\beta_{3}>0\right)$.

Hypothesis H3: Finally, the number of claimholders in each class (LC, SC, and UC) may also influence the delay by increasing both the bargaining process and conflicts of interest because the holdout problem can become more intense (Kennan \& Wilson, 1990). Therefore, we expect a positive sign in our regressions $\left(>0, \beta_{5}>0\right.$, and $\left.\beta_{6}>0\right)$.

We first ran an OLS regression considering the delay of the full sample. Furthermore, we performed a Poisson regression to estimate the level of delays as a function of our covariates. Since delay is classified as count data (number of days to vote on the reorganization plan), it is correct to run a Poisson regression because our variable takes only a finite and positive number of values. However, the mean-variance equality criteria for Poisson regression models presents the assumption of equidispersion (Poisson regression model estimates are inefficient in cases of overdispersion). We followed Cameron and Trivedi (1990) by tackling the overdispersion concern and ran a negative binomial regression model. We adopted robust standard errors in our regressions to adjust for heteroskedasticity problems. We also provide the variance inflation factor (VIF) in Table 6 to show that our data do not present multicollinearity problems. We also control for year fixed effects.

\section{Results}

The first part of our analysis captures how delays depend on the reorganization plan characteristics. Table 7 presents this segregation. By separating the types of delay according to the quorum and claimholder groups (Panel A), we show that unsecured and labor creditors are the main parties responsible for quorum delays.

The same number of observations is available for votes that are delayed when only unsecured creditors and both unsecured and labor creditors do not attend the first general meeting call. Individually, labor claimholders are the second highest cause of delayed votes because of quorum requirements in the first assembly. There are limited cases in which secured creditors are responsible for delaying the vote because of quorum requirements. This result shows that secured creditors are usually not responsible for delaying the vote through their lack of attendance. This group consists of several creditors in Brazil, and they appear to be the most frequently present class of claimholders during the meetings.

It is also interesting to observe that labor and unsecured creditors jointly cause quorum delays in many cases. These classes usually have a large number of creditors, and when the value of the debt is more dispersed among creditors many claimholders may ignore the reorganization case because the associated costs of attendance may be higher than the value they will receive. For example, the costs associated with hiring a lawyer for the case may be higher than a particular claim a creditor owns. Additionally, we identified several cases in our sample in which the labor class of creditors was represented as a group. It appears that a voting strategy similar to that employed by Chapter 11, in which claims administrators collect all the votes, could help reduce the problem of quorum-related delays.

Table 7 shows that several cases of delay were caused by creditors' demands. The assembly minutes reveal that creditors occasionally argue against a specific condition of the plan and request changes or the debtor may realize that it will need to provide better terms to obtain the approval of the creditors during the meeting. In addition, the debtor may begin the general meeting by requesting a delay of several days because new conditions must be delineated in the plan.

Table 6.

Variance Inflation Factor

\begin{tabular}{cc}
\hline Variables & VIF \\
\hline Class Concentration & 1.40 \\
Conc. Top 10 & 1.26 \\
\# of Banks & 1.09 \\
\# of Labor Debtholders & 1.37 \\
\# of Sec. Debtholders & 1.77 \\
\# of Unsec. Debtholders & 1.32 \\
Type & 1.19 \\
Payment - years & 1.08 \\
Sector return & 1.22 \\
Mean VIF & 1.30 \\
\hline
\end{tabular}


Table 7.

\section{Number of observations and average delay by different groups}

\begin{tabular}{|c|c|c|c|c|c|}
\hline \multicolumn{6}{|c|}{ Panel A: Number of Observations } \\
\hline \multirow{2}{*}{ Group } & \multicolumn{2}{|c|}{ By Reason } & \multicolumn{3}{|c|}{ By Meeting } \\
\hline & Quorum & Group Demand & 1st Meeting & 2nd Meeting & 3rd Meeting \\
\hline Recovering Company & NA & 24 & 4 & 17 & 3 \\
\hline Labor Only & 12 & 2 & 13 & 1 & 0 \\
\hline Labor and Unsec. Only & 14 & 0 & 14 & 0 & 0 \\
\hline Labor, Sec., and Unsec. & 4 & 0 & 4 & 0 & 0 \\
\hline Sec. Only & 1 & 2 & 3 & 0 & 0 \\
\hline Sec. and Unsec. Only & 3 & 0 & 3 & 0 & 0 \\
\hline All classes & 1 & 0 & 1 & 0 & 0 \\
\hline Unsec. Only & 14 & 4 & 17 & 1 & 0 \\
\hline Unsec. and Labor Only & 11 & 0 & 11 & 0 & 0 \\
\hline \multicolumn{6}{|c|}{ Panel B: Average Delay } \\
\hline & \multirow{2}{*}{ All Sample } & \multirow{2}{*}{ Quorum } & \multirow{2}{*}{ Demand } & \multicolumn{2}{|c|}{ Demanded by } \\
\hline & & & & Creditor & Debtholders \\
\hline (1) Three Classes & 22 & 34 & 12 & 47 & 12 \\
\hline (2)Two Classes & 20 & 22 & 16 & & 16 \\
\hline (3) Unsec. and Labor & 21 & 25 & 9 & & 9 \\
\hline (4) Sec. and Unsec. & 18 & 10 & 22 & & 22 \\
\hline (5) One Class (unsec.) & 9 & 14 & 3 & & 3 \\
\hline $\mathrm{t}$-test $(1-2)$ & 0.41 & 1.40 & -0.55 & & -0.55 \\
\hline $\mathrm{t}$-test $(2-5)$ & 1.95 & 1.10 & 1.78 & & 1.78 \\
\hline
\end{tabular}

Because many creditors hire a lawyer to attend the meeting, it is nearly always the case that these lawyers will request a delay to explain the modifications proposed in the assembly to their clients. In several cases, creditors vote on the plan without requesting modifications. We found that in most cases, the debtor requests a delay to prepare a modification to the original plan in order to convince the secured creditors class.

Therefore, it is clear that the delays caused by quorum requirements are usually caused by unsecured and labor creditors and that further delays are related to debtors modifying the original plan according to the suggestions made by the different classes of claimholders. In our sample, a maximum of three rounds of delays are required. In addition to the evolution of the quorum attendance for each creditor class, we show the delays segregated by rounds. This finding indicates the delay between the meetings based on the type of delay in voting on the plan.

In cases in which there is no delay in the first meeting because of quorum requirements, the bargaining process may intensify, and the debtor may request a postponement in the assembly to prepare a better plan according to the creditors' indications. Because a creditor delay (at least for labor and unsecured classes) in the first meeting is usually caused by a quorum requirement, the median period of days for the delay is short. However, when the delay is caused by suggestions from the secured class of creditors in the first meeting, the period of days for the delay is closer to that caused by the debtor for implementing modifications to the reorganization plan. Similarly, the median period of days for delays caused by unsecured creditors in the second meeting is slightly greater than that caused by the debtor for second meetings.

One possible explanation for this result may be that the incentives for unsecured creditors are more closely aligned with those for equity holders. Therefore, it is logical to propose modifications that prevent the plan from being rejected during the meeting. According to the data, the negotiations become more intense after the first round. In our sample, the only case in which a delay caused by labor creditors was not quorum-related occurred because the debtor was close to providing a new asset evaluation to sell its assets and pay all labor debt.

Table 8 provides the grouping of companies according to the profitability of their sector. The average 
delay is longer when the earnings for the sector are lower for the secured and unsecured classes. Worse economic conditions in the sector to which a firm belongs appear to matter, particularly in delays demanded by secured and unsecured creditors. In such conditions, the debtor's strategy to continue operations becomes less reliable because positive future cash flows may be more difficult to obtain.
We believe that our regression analysis may corroborate the results obtained by the descriptive analysis. Table 9 shows the result for the OLS, Poisson, and negative binomial regressions of the delays considering our full sample. We also control for year fixed effects in each regression model. The delay variable continues to be the time interval (in days) between the first general meeting

Table 8.

\section{Average delay and number of observations in the subsamples divided by sector return}

\begin{tabular}{|c|c|c|c|c|}
\hline \multicolumn{5}{|c|}{ Average Delay } \\
\hline Class/Sector Return & $<2 \%$ & $\geq 2 \%,<5 \%$ & $\geq 5 \%,<7 \%$ & $\geq 7 \%$ \\
\hline Labor & 28 & 30 & 30 & 31 \\
\hline Sec. & 28 & 55 & & 13 \\
\hline Unsec. & 43 & 10 & 8 & 7 \\
\hline t-test (L-S) & 0.2 & & & 8.3 \\
\hline $\mathrm{t}$-test $(\mathrm{S}-\mathrm{U})$ & -2.7 & & & 3.6 \\
\hline \multicolumn{5}{|c|}{ Number of Observations } \\
\hline Class/Sector Return & $<2 \%$ & $\geq 2 \%,<5 \%$ & $\geq 5 \%,<7 \%$ & $\geq 7 \%$ \\
\hline Labor & 6 & 4 & 13 & 19 \\
\hline Sec. & 2 & 1 & 0 & 4 \\
\hline Unsec. & 2 & 2 & 4 & 3 \\
\hline
\end{tabular}

Note: This table reports the average delay and the number of observations in $2 \times 4$ groups separated into the groups causing the delay and the profitability of each sector. We used the Bloomberg sectors to classify the companies in sectors, and then we used the average EBITDA divided by the total book value of all of the listed companies as a measure of profitability of a given sector in a given year.

Table 9.

\section{Regressions}

\begin{tabular}{|c|c|c|c|}
\hline \multicolumn{4}{|c|}{ Dependent Variable: Delay (Days) } \\
\hline & OLS & Poisson & Negative Binomial \\
\hline & (1) & $(2)$ & (3) \\
\hline \multirow[t]{2}{*}{ Class Concentration (\%) } & $-70.102^{*}$ & $-2.856^{* *}$ & $-2.179 *$ \\
\hline & $(39.933)$ & $(0.962)$ & $(1.231)$ \\
\hline \multirow[t]{2}{*}{ Conc. Top $10(\%)$} & 2.523 & 0.076 & -0.483 \\
\hline & $(35.080)$ & $(0.845)$ & $(1.01)$ \\
\hline \multirow[t]{2}{*}{ Number of Banks (\#) } & $2.915^{*}$ & $0.120^{* * *}$ & $0.092^{* *}$ \\
\hline & $(1.581)$ & $(0.045)$ & $(0.044)$ \\
\hline \multirow[t]{2}{*}{ Number of Labor (\#) } & 0.0005 & 0.001 & -0.0001 \\
\hline & $(0.026)$ & $(0.007)$ & $(0.006)$ \\
\hline \multirow{2}{*}{ Number of Secured (\#) } & $3.909^{* *}$ & $0.097^{* * *}$ & $0.0634^{*}$ \\
\hline & $(1.637)$ & $(0.026)$ & $(0.035)$ \\
\hline \multirow{2}{*}{ Number of Unsecured (\#) } & -0.010 & -0.003 & -0.0005 \\
\hline & $(0.023)$ & $(0.004)$ & $(0.0006)$ \\
\hline \multirow[t]{2}{*}{ Type (S.A dummy) } & 3.747 & -0.062 & -0.051 \\
\hline & $(15.456)$ & $(0.359)$ & $(0.376)$ \\
\hline \multirow[t]{2}{*}{ Payment - years } & $3.643^{* * *}$ & $0.144^{* * *}$ & $0.125^{* * *}$ \\
\hline & $(1.374)$ & $(0.037)$ & $(0.039)$ \\
\hline \multirow[t]{2}{*}{ Sector Return } & -492.1935 & -13.934 & -6.670 \\
\hline & $(421.065)$ & (9.423) & (9.198) \\
\hline Year FE? & Yes & Yes & Yes \\
\hline Observations & 90 & 90 & 90 \\
\hline $\mathrm{R}^{2}$ & 0.32 & & \\
\hline Pseudo R2 & & 0.49 & 0.43 \\
\hline
\end{tabular}

Note: The symbols ${ }^{* *},{ }^{* *}$, and ${ }^{\star}$ denote significance at the $1 \%$ level, $5 \%$ level, and $10 \%$ level, respectively. Robust standard errors are shown in parentheses. The variables are defined in Table 1. 
Table 10.

Characteristics of delays segregated by quartiles

\begin{tabular}{ccccccc}
\hline Delay & \multicolumn{5}{c}{ Proposal of Payment to Claimholders (\% of Cases) } \\
\cline { 1 - 5 } & Debt Discount & Grace Period & Interest Rate & Payback Period & Divestment & Claims Exchange \\
\hline$>75 \%$ & 25 & 0 & 25 & 8.33 & 33.33 & 33.33 \\
$>50 \%$ and $<75 \%$ & 22.22 & 33.33 & 44.44 & 55.56 & 33.33 & 22.22 \\
$>25 \%$ and $<50 \%$ & 9.09 & 18.18 & 18.18 & 27.27 & 18.18 & 0 \\
$<25 \%$ & 10 & 0 & 40 & 20 & 0 & 10 \\
\hline
\end{tabular}

Note: This table reports the percentage of modifications for different payment proposals according to the delays. The debt discount is the portion of debt discounted from the original debt value. The grace period is the period from the plan vote to the first creditor payment. The interest rate reports the form of interest on debt payments. The payback period is the time stated by the firms to settle their debt. Divestment is an offer to sell assets. Claims exchange shows the number of cases where creditors did not agree with the firm regarding the value of debt to be paid and requested certain changes during the general meeting.

and the final meeting at which the reorganization plan receives a vote. As we had no balanced information for each variable for our firms, we lost some observations when running our regressions.

Table 9 indicates that the coefficient of the Class Concentration variable is negative and significant. This finding is consistent with hypothesis $\mathrm{H} 1$ of this study, and we believe that the explanation is simple. Because a higher concentration of funding in one claimholder class increases the alignment of all perspectives, creditors are expected to adopt a consensus decision more quickly relative to situations in which the claims are more dispersed between the creditor classes.

Therefore, a higher concentration of claims in a specific class may help to reduce issues related to creditor coordination and holdouts. Our results are consistent with that of Ivashina et al. (2016). Moreover, we also find a positive and statistically significant result for the number of banks and the number of secured creditors in our regressions. As presented by Kennan and Cai (2000) and Wilson (1990), more creditors voting on the plan is associated with longer delays.

Moreover, in Brazil, secured creditors are generally banks. We showed that more banks being part of the reorganization process makes the resolution more complex and the bargaining process more intense, since more banks are associated with longer delays. We corroborate the results of Helwege (1999), who specifies that bank debt is positively related to lower levels of debt restructuring. We also show that more years to settle the firm debt relates to longer delays.
Table 10 shows that reorganization plans that require a greater amount of time until the final vote are correlated with divestment proposals. This reveals that many rounds of discussions are required to choose the assets that should be sold to generate funds. Table 10 also presents the general proposal for payment to claimholders segregated by delay quartiles. Longer delays also present a higher portion of debt discount.

Finally, one can argue that our previous results may present some complications even after winsorization (average analyses are sensitive to the presence of some outliers). Hence, we also ran a quantile regression model for our previous specification. Table 11 provides the results for our three quantile specifications $(25 \%, 50 \%$, and $75 \%$ ). We note that our main results remain robust.

\section{Conclusions}

In this paper, we studied the characteristics of vote delays during reorganizations based on a sample of 120 Brazilian firms from 2005 to 2015 . To the best of our knowledge, this is the first paper to evaluate delays in reorganization plan votes according to each player's interaction in the assembly.

We believe that this paper contributes to the literature on reorganization and bankruptcy by providing important insights into the characteristics of associated delays. Our results indicate that a higher concentration of claims is negatively correlated with delays. We found that a concentration of funding during restructuring may influence voting delays because of requirements that originate from the debtor and creditors; however, this 


\section{Table 11.}

\section{Quantile Regressions}

\begin{tabular}{|c|c|c|c|}
\hline & \multicolumn{3}{|c|}{ Dependent Variable: Delay (Days) } \\
\hline & \multicolumn{3}{|c|}{ Quantile Regressions } \\
\hline & $(25 \%)$ & $(50 \%)$ & $(75 \%)$ \\
\hline \multirow[t]{2}{*}{ Class Concentration } & -12.628 & $-48.431^{*}$ & -25.984 \\
\hline & $(23.538)$ & $(28.370)$ & $(39.828)$ \\
\hline \multirow[t]{2}{*}{ Conc. Top $10(\%)$} & 9.0680 & 12.714 & 5.002 \\
\hline & $(19.509)$ & $(22.550)$ & $(37.327)$ \\
\hline \multirow[t]{2}{*}{ Number of Banks (\#) } & $2.588^{* * *}$ & $2.296^{* *}$ & $4.237^{* * *}$ \\
\hline & $(0.8858)$ & $(1,143)$ & $(1.551)$ \\
\hline \multirow[t]{2}{*}{ Number of Labor Debtholders (\#) } & 0.005 & 0.020 & -0.022 \\
\hline & $(0.0187)$ & $(0.017)$ & $(0.2488)$ \\
\hline \multirow{2}{*}{ Number of Sec. Debtholders (\#) } & $1,754^{*}$ & $2.855^{* *}$ & $2.608^{*}$ \\
\hline & $(1.024)$ & $(1.093)$ & $(1.480)$ \\
\hline \multirow[t]{2}{*}{ Number of Unsec. Debtholders (\#) } & -0.009 & -0.025 & -0.004 \\
\hline & $(0.0140)$ & $(0.016)$ & $(0.040)$ \\
\hline \multirow[t]{2}{*}{ Type } & -4.466 & -1.892 & 1.828 \\
\hline & $(16.781)$ & $(14.506)$ & $(13.73)$ \\
\hline \multirow[t]{2}{*}{ Payment - years } & 1.202 & $2,120^{*}$ & 1.724 \\
\hline & $(0.844)$ & $(1,219)$ & $(1.883)$ \\
\hline \multirow[t]{2}{*}{ Sector Return } & -423.780 & -693.390 & -29.076 \\
\hline & $(369.638)$ & $(428.337)$ & $(452.975)$ \\
\hline Year FE? & Yes & Yes & Yes \\
\hline Observations & 89 & 89 & 89 \\
\hline $25 \%$ - Pseudo $\mathrm{R}^{2}$ & 0.119 & & \\
\hline $50 \%$ - Pseudo $\mathrm{R}^{2}$ & & 0.2388 & \\
\hline $75 \%$ - Pseudo R2 & & & 0.39 \\
\hline
\end{tabular}

Note. The symbols ${ }^{* *},{ }^{* *}$, and ${ }^{\star}$ denote significance at the $1 \%$ level, $5 \%$ level, and $10 \%$ level, respectively.

factor does not appear to affect the creditors' decision to avoid appearing at the first assembly.

Our results also show that for longer periods of delay, the concentration of claims among classes remains significant and retains the same sign. Moreover, the number of banks and secured creditors participating in the reorganization is positively correlated with longer delays.

This paper has certain limitations. Our econometric results only corroborate our descriptive analysis by controlling the delay analysis with greater groups of variables to show a relationship. Thus, future research should be conducted to demonstrate causality between the claimholder classes and voting delays.

\section{References}

Adler, B. E., Capkun, V., \& Weiss, L. A. (2013). Value destruction in the new era of chapter 11. The Journal of Law, Economics, \& Organization, 29(2), 461-483.

Admati, A. R., \& Perry, M. (1987). Strategic delay in bargaining. The Review of Economic Studies, 54(3), 345-364.

Asquith, P., Gertner, R., \& Scharfstein, D. (1994). Anatomy of financial distress: An examination of junk-bond issuers. The Quarterly Journal of Economics, 109(3), 625-658.

Anapolsky, J. M., \& Woods, J. F. (2013). Pitfalls in Brazilian bankruptcy law for international bond investors. Journal of Business \& Technology Law, 8(2), 397-450. 
Araujo, A. P., Ferreira, R. V. X., \& Funchal B. (2012). The Brazilian bankruptcy law experience. Journal Corporate Finance 18(4), 994-1004.

Ayotte, K. M., \& Morrison, E. R. (2009). Creditor control and conflict in Chapter 11. Journal of Legal Analysis, 1(2), 511-551.

Baird, D. G., \& Rasmussen, R. K., 2002. The end of bankruptcy. Stanford Law Review, 55(173), 751-789.

Broadie, M., Chernov M., \& Sundaresan, S. (2007). Optimal debt and equity values in the presence of Chapter 7 and Chapter 11. The Journal of Finance 62(3), 1341-1377.

Brown, D. T., James, C. M., \& Mooradian, R. M. (1993). The information content of distressed restructurings involving public and private debt claims. Journal of Financial Economics, 33(1), 93-118.

Cai, H. (2000). Delay in multilateral bargaining under complete information. Journal of Economic Theory, 93(2), 260-276.

Cameron, A. C., \& Trivedi, P. K. (1990). Regression-based tests for overdispersion in the Poisson Model. Journal of Econometrics, 46(3), 347-364.

Das, D. K., Ghosh, S., \& Subudhi, B. (2014). Tolerable delay-margin improvement for systems with input-output delays using dynamic delayed feedback controllers. Applied Mathematics and Computation, 230(1), 57-64.

Franks, J. R., \& Torous, W. N. (1994). A comparison of financial recontracting in distressed exchanges and Chapter 11 reorganizations. Journal of Financial Economics, 35(3), 349-370.

Gale, D. (1995). Dynamic coordination games. Economic Theory, 5(1), 1-18.

Gilson, S. C. (1990). Bankruptcy, boards, banks, and blockholders: Evidence on changes in corporate ownership and control when firms default. Journal of Financial Economics, 27(2), 355-387.

Gilson, S. C., John, K., \& Lang, L. H. P. (1990). Troubled debt restructurings: An empirical study of private reorganization of firms in default. Journal of Financial Economics, 27(2), 315-353.
Helwege, J. (1999). How long do junk bonds spend in default? The Journal of Finance, 54(1), 341-357.

Hotchkiss, E. S. (1995). Postbankruptcy performance and management turnover. The Journal of Finance, 50(1), 3-21.

Ivashina, V., Iverson, B., \& Smith, D. C. (2016). The ownership and trading of debt claims in Chapter 11 restructurings. Journal of Financial Economics, 119(2), 316-335.

Iverson, B. (2017). Get in line: Chapter 11 restructuring in crowded bankruptcy courts. Management Science, 64(11), 4967-5460.

James, C. (1996). Bank debt restructurings and the composition of exchange offers in financial distress. The Journal of Finance, 51(2), 711-727.

Kalay, A., Singhal, R., \& Tashjian, E. (2007). Is chapter 11 costly? Journal of Finance Economics, 84(3), 772-796.

Kaplan, S. N., \& Stromberg, P. (2003). Financial contracting theory meets the real world: An empirical analysis of venture capital contracts. The Review of Economic Studies, 70(2) 281-315.

Kennan, J., \& Wilson, R. (1990). Theories of bargaining delays. Science, 249(4973), 1124-1128.

LoPucki, L. M. 2003. The nature of the bankrupt firm: A response to Baird and Rasmussen's 'the end of bankruptcy'. Stanford Law Review, 56(3), 645-671.

Ponticelli, J. 2012. Court enforcement and firm productivity: Evidence from a bankruptcy reform in Brazil. Bocconi, Barcelona.

Rubinstein, A. (1982). Perfect equilibrium in a bargaining model. Econometrica, 50(1), 97-109.

Senbet, L. W., \& Wang, T. Y. (2010). Corporate financial distress and bankruptcy: A survey. Foundations and trends in finance, 5(4), 243-335

Silva, V. A. B., Sampaio, J. O., \& Gallucci, H., Netto. (2018). Pedidos de recuperação judicial no Brasil: Uma explicação com variáveis econômicas. Revista Brasileira de Finanças 16(3), 429-454. 
Silva, V. A. B., \& Saito, R. (2018). Corporate restructuring: Empirical evidence on the approval of the reorganization Plan. RAUSP Management Journal 53(1), 49-62.
Zhang, J., Knopse, C. R., \& Tsiotras, P. (2001). Stability of time-delay systems: Equivalence between Lyapunov and Scaled small-gain conditions. IEEE Transactions on Automatic Control 46(3), 482-486. 


\section{Authors:}

1. Vinicius Augusto Brunassi Silva, Doctor in Business Administration (Finance), FGV, Sao Paulo, Brazil.

E-mail: vinicius.brunassi@fecap.br

ORCID

(D) 0000-0002-1299-321X

2. Richard Saito, PhD in Engineering-Economic Systems, Stanford University, California, USA.

E-mail: rsaito@finenge.com

ORCID

(D) 0000-0002-9512-9071

3. Paulo Martins Manoel, PhD, University of California at Berkeley, California, USA.

E-mail: paulo.manoel@uky.edu

ORCID

(D) 0000-0002-8111-2834

4. Mariana Aparecida Calabrez Oreng, Master in Business Administration (Finance), FGV, Sao Paulo, Brazil.

E-mail: mariana.oreng@gmail.com

ORCID

(D) $0000-0002-7266-6560$

\section{Contribution of each author}

\begin{tabular}{|c|c|c|c|c|}
\hline Contribution & $\begin{array}{l}\text { Vinicius } \\
\text { Brunassi }\end{array}$ & $\begin{array}{c}\text { Richard } \\
\text { Saito }\end{array}$ & $\begin{array}{c}\text { Paulo } \\
\text { Manoel }\end{array}$ & $\begin{array}{c}\text { Mariana } \\
\text { Oreng }\end{array}$ \\
\hline 1. Definition of research problem & $\sqrt{ }$ & $\sqrt{ }$ & $\sqrt{ }$ & \\
\hline 2. Development of hypotheses or research questions (empirical studies) & $\sqrt{ }$ & $\sqrt{ }$ & $\sqrt{ }$ & \\
\hline 3. Development of theoretical propositions (theoretical work) & $\sqrt{ }$ & $\sqrt{ }$ & & \\
\hline 4. Theoretical foundation/literature review & $\sqrt{ }$ & $\sqrt{ }$ & & \\
\hline 5. Definition of methodological procedures & $\sqrt{ }$ & & $\sqrt{ }$ & \\
\hline 6. Data collection & $\sqrt{ }$ & & & $\sqrt{ }$ \\
\hline 7. Statistical analysis & $\sqrt{ }$ & & $\sqrt{ }$ & \\
\hline 8. Analysis and interpretation of data & $\sqrt{ }$ & $\sqrt{ }$ & $\sqrt{ }$ & \\
\hline 9. Critical revision of the manuscript & $\sqrt{ }$ & $\sqrt{ }$ & $\sqrt{ }$ & $\sqrt{ }$ \\
\hline 10. Manuscript writing & $\sqrt{ }$ & $\sqrt{ }$ & & $\sqrt{ }$ \\
\hline 11. Other (please specify which) & & & & \\
\hline
\end{tabular}

